\title{
Self-Assessment of Hearing and Purchase of Hearing Aids by Middle-Aged and Elderly Adults
}

\author{
Andressa Colares da Costa Otavio ${ }^{1}$ Patricia Pérez Coradini ${ }^{2} \quad$ Adriane Ribeiro Teixeira $^{3}$ \\ 1 Speech Therapy Course, Universidade Federal do Rio Grande do Sul, \\ Porto Alegre, Rio Grande do Sul, Brazil \\ ${ }^{2}$ Fgda, Comunicare Aparelhos Auditivos, Porto Alegre, Rio Grande do \\ Sul, Brazil \\ ${ }^{3}$ Department of Health and Human Communication, Universidade \\ Federal do Rio Grande do Sul, Instituto de Psicologia da UFRGS, Porto

\begin{abstract}
Address for correspondence Adriane Ribeiro Teixeira, PhD, Department of Health and Human Communication - Instituto de Psicologia, Universidade Federal do Rio Grande do Sul, Instituto de Psicologia da UFRGS, Rua Ramiro Barcelos, 2777, sala 315, Porto Alegre, Rio Grande do Sul 90035003, Brazil (e-mail: adriane.teixeira@gmail.com).
\end{abstract} Alegre, Rio Grande do Sul, Brazil

Int Arch Otorhinolaryngol 2016;20:48-53.

\begin{abstract}
Introduction Presbycusis is a consequence of aging. Prescription of hearing aids is part of the treatment, although the prevalence of use by elderly people is still small.

Objective To verify whether or not self-assessment of hearing is a predictor for purchase of hearing aids.

Methods Quantitative, cross-sectional, descriptive, and observational study. Participants were subjects who sought a private hearing center for selection of hearing aids. During the diagnostic interview, subjects answered the following question: "On a scale of 1 to 10 , with 1 being the worst and 10 the best, how would you rate your overall hearing ability?" After that, subjects underwent audiometry, selected a hearing aid, performed a home trial, and decided whether or not to purchase the hearing aid. The variables were associated and analyzed statistically.

Results The sample was comprised of 32 subjects, both men and women, with a higher number of women. Mean age was $71.41 \pm 12.14$ years. Self-assessment of hearing ranged from 2 to 9 points. Overall, $71.9 \%$ of the subjects purchased hearing aids. There was no association between scores in the self-assessment and the purchase of hearing aids $(p=0.263)$. Among those who scored between 2 and 5 points, $64.7 \%$

Keywords

- self-assessment

- hearing aids

- elderly purchased the device; between 6 and 7 points, 76.09\% purchased the device; and between 8 and 9 points, 50\% purchased the device, respectively.

Conclusion There is evidence that low self-assessment scores lead to the purchase of hearing aids, although no significant association was observed in the sample.
\end{abstract}

\section{Introduction}

Similar to other countries, the age structure in Brazil is changing, with an increase of the elderly population. The number of elderly people has increased, and they are living longer. Currently, life expectancy at birth is 74.6 years, ${ }^{1}$ compared with 66 years in $1991,{ }^{2}$ which is a red flag to health care professionals, who must be prepared to satisfactorily attend to this population.

In the elderly population, there is prevalence of a type of hearing loss, known as presbycusis. This is an age-related degenerative change, ${ }^{3}$ which causes sensorineural, bilateral, symmetrical, and progressive hearing loss. ${ }^{4,5}$ It is a common misfortune among the elderly, and it starts approximately received

February 12, 2015

accepted

April 18, 2015

published online

June 9, 2015
DOI http://dx.doi.org/

10.1055/s-0035-1554728.

ISSN $1809-9777$.
Copyright $\odot 2016$ by Thieme Publicações License terms

Ltda, Rio de Janeiro, Brazil

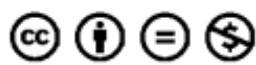


between the third and fifth decade of life; because it is more pronounced in the higher frequencies, it causes difficulties to understand speech, especially in the concomitant presence of noise and speech. ${ }^{6,7}$ These difficulties may be accentuated when there is impairment of auditory information processing or when cognitive disorders occur. ${ }^{8}$

On average, $1 \mathrm{~dB}$ of hearing threshold is lost per year in people aged over 60 years. ${ }^{9}$ Despite the extensive knowledge of presbycusis, there is no clinical method to predict its appearance in advance. There are indications that some factors, such as age, sex, race, genetic and environmental factors, and comorbidities (hypertension, diabetes, etc.) can influence the presence and degree of hearing loss. ${ }^{10}$

In addition to problems directly related to communication, hearing loss in the elderly can contribute to problems such as depression, isolation, and possible dementia ${ }^{11-13}$; in middleaged adults, it is one more change in the midst of a phase in which subjects already face several biopsychosocial changes. ${ }^{14}$ Treatment for presbycusis includes use of hearing aids, but despite the high prevalence of presbycusis in the elderly population, the use of prosthesis is not yet significant, regardless of the country surveyed. A U.S. study found prevalence of $63.1 \%$ for hearing loss and $19.1 \%$ use of hearing aids. There was an association with the degree of loss, education, income, and social activities. ${ }^{15}$ Another North American study showed that $76.4 \%$ of the surveyed elderly saw a doctor because of hearing disorders, but only $34 \%$ started using hearing aids; in contrast, $98.6 \%$ of elderly people with visual impairment sought medical advice and $93.0 \%$ of them wore glasses. ${ }^{16}$ After 5 years of monitoring, researchers of the Blue Mountains Hearing Study found that $8.1 \%$ of the subjects aged 55 to 99 used hearing aids. ${ }^{17}$

In a study on health problems of the elderly, the authors found that $63.1 \%$ of the subjects in the sample self-reported hearing loss. Although prevalence was high, the use of hearing aids was reported by only $1.47 \%$ of subjects. ${ }^{18}$ In a research study conducted with 7,315 elderly people in 59 cities in the Brazilian state of Rio Grande do Sul, 4,300 (58.78\%) of the subjects considered their hearing to be fair, poor, or very poor. Nevertheless, only $3.8 \%$ of all assessed patients used hearing aids. ${ }^{19}$ These statistics reinforce the idea that, although age-related hearing problems are well known, adherence to treatment should be further researched.

Therefore, it is relevant to understand whether self-assessment of hearing could be a predictor for purchase of a hearing aid. A U.S. study questioned patients to see if they were able to proceed to amplification through their self-assessment of hearing. ${ }^{20}$ There was a relationship between patients' opinions about their hearing and their decision to use a hearing aid.

Thus, disadvantages of hearing loss in the elderly and the stages of treatment are already known. There is a need, however, to understand the determinants for the purchase of hearing aids, considering the data presented. Considering that there are few studies in the literature on predictors for the purchase of a hearing aid, especially by the Brazilian population, the aim of this study was to determine whether self-assessment of hearing is a predictor for purchase of hearing aids.

\section{Methods}

This study was approved by the Research Committee and by the Research Ethics Committee of the Institute (protocol 24401). This is a quantitative, cross-sectional, descriptive, and observational study. The sample consisted of middleaged and elderly adults, interested in having hearing aid tests, seen at a private hearing center located in the city of Porto Alegre (Rio Grande do Sul, Brazil).

Inclusion criteria were diagnosis of hearing loss, medical prescription of hearing aid use, signing of the informed consent form, and collaboration with the study procedures. The study excluded elderly people who refused to participate voluntarily, who did not follow any of the study procedures, or who had a history of cognitive, psychiatric, or neurologic impairment (checked during the diagnostic interview).

Patients who met the inclusion criteria continued in the study. During the diagnostic interview, patients answered the following question: "On a scale of 1 to 10 , with 1 being the worst and 10 the best, how would you rate your overall hearing ability?"20

The subsequent steps were pure tone audiometry, selection and home trial of hearing aids, and decision to purchase the hearing aid or not. Within 2 to 3 weeks after the diagnostic interview, a query to the auditory center database was made to verify whether or not the patient had purchased the prosthesis.

For analysis of audiometric data, hearing loss were classified as conductive, mixed, or sensorineural. ${ }^{21}$ For measuring degree of loss, the classification by the World Health Organization was used, ${ }^{22}$ considering the average of the hearing thresholds at 500, 1,000, 2,000, and 4,000 Hz. Under this classification, average values between -10 and $25 \mathrm{dBHL}$ indicate normal hearing; between $26 \mathrm{~d}$ and $40 \mathrm{dBHL}$, mild hearing loss; between 41 and $60 \mathrm{dBHL}$, moderate hearing loss; between 61 and $80 \mathrm{dBHL}$, severe hearing loss; and values higher than $81 \mathrm{dBHL}$, profound hearing loss. ${ }^{22}$

Initially, the values obtained in the collection of data were analyzed using descriptive statistics, through absolute $(n)$ and relative (\%) distribution, and the mean, standard deviation, and median were analyzed with the study of symmetry by the Shapiro-Wilk test. In the comparison of continuous variables between the purchase and nonpurchase of prosthesis, the Mann-Whitney test was used. When the comparison was made with categorical variables, Fisher exact test was implemented. Analyses were performed using software SPSS (Statistical Package for Social Sciences, IBM, USA) version 2.0. For statistical decision criteria, the $5 \%$ significance level was used.

\section{Results}

The results shown refer to a sample of 32 subjects, whose characteristics and audiological results are shown in -Tables $\mathbf{1}$ and 2, respectively. Mean age was $71.41 \pm 12.14$ years; there was a higher number of women (59.4\%) and of new users of hearing aids (68.75\%). Most of the assessed patients had bilateral, sensorineural, and moderate 
Table 1 Sample characterization

\begin{tabular}{|l|l|l|}
\hline Variable & $\boldsymbol{n}$ & Results \\
\hline Age $(\mathrm{y})$ & & \\
\hline Mean and standard deviation & 32 & $71.41 \pm 12.14$ \\
\hline Minimum & 1 & 45 \\
\hline Maximum & 1 & 93 \\
\hline Gender & & \\
\hline Men & 13 & $40.6 \%$ \\
\hline Women & 19 & $59.4 \%$ \\
\hline New user & & \\
\hline Yes & 22 & $68.75 \%$ \\
\hline Not answered & 1 & $3.12 \%$ \\
\hline Not & 9 & $28.13 \%$ \\
\hline Unilateral user & 6 & $66.67 \%$ \\
\hline Bilateral user & 1 & $11.11 \%$ \\
\hline Not answered & 2 & $22.22 \%$ \\
\hline
\end{tabular}

hearing loss in both ears. Hearing aids were purchased by 22 individuals (71.9\%).

Considering the scores awarded by the subjects in their self-assessment of hearing and the number of subjects in the sample, the values were grouped for carrying out the analysis, similar to what was done by Palmer et al. ${ }^{20}$ Groups were sorted as follows: values of up to 5 points, between 6 and 7 points, and between 8 and 10 points.

The results showed that $64.7 \%$ of the individuals who scored their hearing with values between 2 and 5 purchased the hearing aid, and $76.09 \%$ of those who scored their hearing between 6 and 7 purchased the hearing aid. Purchase of the hearing aid was $50 \%$ for those who self-assessed their hearing with scores between 8 and 9. Still, there was no association between self-assessment of hearing and purchase of hearing aids ( $p=0.263$; - Table 3 ).

Because the analysis showed no association between the categories we created, we decided to analyze the data continuously. After comparing the scores of the question with the purchase of the hearing aids ( - Table 4 ), again there was no statistically significant difference $(p=0.688)$, which is indicative that the variations between the elderly subjects who purchased the hearing aids $(5.3 \pm 1.6)$ and those who did not purchase it $(5.0 \pm 1.8)$ cannot be associated with purchase of hearing aid in the study sample.

\section{Discussion}

Data analysis showed that the mean age of the individuals was $71.41 \pm 12.14$ years. Considering that age-related hearing loss begins in the third decade of life and is progressive, ${ }^{4,5,7}$ it is likely that subjects in the sample had already been experiencing hearing difficulties for some time. Among the participants of the Beaver Dam Eye Study, 20\% of people who were monitored for 10 years purchased hearing aids 5 to
Table 2 Audiological sample characterization

\begin{tabular}{|c|c|c|}
\hline Variable & $n$ & Results \\
\hline \multicolumn{3}{|l|}{ Mean right ear $(\mathrm{dB})$} \\
\hline Mean and standard deviation & 32 & $51.72 \pm 19.11$ \\
\hline Minimum & 1 & 10 \\
\hline Maximum & 1 & 92.5 \\
\hline \multicolumn{3}{|l|}{ Mean left ear (dB) } \\
\hline Mean and standard deviation & 32 & $52.72 \pm 18.6$ \\
\hline Minimum & 1 & 18.75 \\
\hline Maximum & 1 & 99.5 \\
\hline \multicolumn{3}{|l|}{ Unilateral or bilateral hearing loss } \\
\hline Bilateral & 30 & $93.74 \%$ \\
\hline Unilateral right ear & 1 & $3.13 \%$ \\
\hline Unilateral left ear & 1 & $3.13 \%$ \\
\hline \multicolumn{3}{|l|}{ Degree of loss right ear ${ }^{a}$} \\
\hline Mild & 4 & $12.9 \%$ \\
\hline Moderate & 18 & $58.06 \%$ \\
\hline Severe & 7 & $22.58 \%$ \\
\hline Profound & 2 & $6.45 \%$ \\
\hline \multicolumn{3}{|l|}{ Degree of loss left ear ${ }^{a}$} \\
\hline Mild & 4 & $12.9 \%$ \\
\hline Moderate & 18 & $58.06 \%$ \\
\hline Severe & 8 & $25.8 \%$ \\
\hline Profound & 1 & $3.22 \%$ \\
\hline \multicolumn{3}{|l|}{ Type of loss right ear ${ }^{a}$} \\
\hline Sensorineural hearing loss & 26 & $83.87 \%$ \\
\hline Mixed hearing loss & 5 & $16.13 \%$ \\
\hline \multicolumn{3}{|l|}{ Type of loss left ear ${ }^{a}$} \\
\hline Sensorineural hearing loss & 24 & $77.42 \%$ \\
\hline Mixed hearing loss & 7 & $22.58 \%$ \\
\hline \multicolumn{3}{|l|}{ Hearing aid purchase } \\
\hline Yes & 22 & $68.75 \%$ \\
\hline Not & 10 & $31.25 \%$ \\
\hline
\end{tabular}

${ }^{\mathrm{a} O n l y}$ ears with hearing loss were considered.

10 years after detection of hearing loss. ${ }^{23}$ The present research found that the majority of participants were new users, but 9 subjects (28.13\%) had been using prosthesis prior to joining the study; a significant portion of the sample had already become aware of the effects of hearing loss.

A higher number of women (59.4\%) was also found, although the literature asserts that presbycusis is more pronounced in men, ${ }^{24}$ which is believed to be due to the fact that men look for health care services less often than women. ${ }^{25}$

Analysis of audiological data showed that the average of hearing thresholds was $51.72 \mathrm{dBHL}$ in the right ear and 51.72 $\mathrm{dBHL}$ in the left ear, which characterizes moderate hearing loss. The most prevalent type of hearing loss was 
Table 3 Absolute and relative distribution for self-evaluation by the purchase of hearing aids

\begin{tabular}{|c|c|c|c|c|c|}
\hline \multirow[t]{3}{*}{ Self-evaluation } & \multicolumn{4}{|c|}{ Hearing aid purchase ${ }^{a}$} & \multirow[t]{3}{*}{$p$ Value $^{b}$} \\
\hline & \multicolumn{2}{|c|}{ Yes $(n=22)$} & \multicolumn{2}{|c|}{ Not $(n=10)$} & \\
\hline & $n$ & $\%$ & $n$ & $\%$ & \\
\hline $2-5$ & 11 & 64.7 & 6 & 35.3 & \\
\hline $6-7$ & 10 & 76.9 & 3 & 23.1 & 0.263 \\
\hline $8-9$ & 1 & 50.0 & 1 & 50.0 & \\
\hline
\end{tabular}

apercentages obtained based on the total number of cases in each category of the acquisition of prosthesis.

bisher exact test (for Monte Carlo simulation).

sensorineural, as expected by the researchers of the present study. The type and degree of hearing loss observed are typical of age-related hearing loss. ${ }^{26,27}$ Bilateral hearing loss was prevalent in 30 subjects (93.74\%); one subject had unilateral loss in the right ear and another in the left ear. This also was expected, as it is one of the characteristics of presbycusis. $^{4,5}$

Although there was no significant association between self-assessment and purchase of hearing aid $(p=0.263)$, most purchases were made by subjects whose self-assessments scored 2 to 7 points. Of the 32 subjects of the sample, 30 scored between 2 and 7, and 21 of them (70\%) purchased hearing aids. Only 2 subjects scored between 8 and 9; one of them purchased the hearing aid and the other one did not. A qualitative analysis of the data shows that the score may indicate predictive values. Subjects whose self-assessment score range between 2 and 7 are 2.3 times more likely to purchase a hearing aid than otherwise. This finding corroborates previous findings in which self-perception of hearing loss increases more than three times the rate of purchase of a hearing aid. ${ }^{23}$

In a study that gave rise to the research question, it was found that $0 \%$ of those who scored between 9 and 10 continued to amplification compared with $18 \%$ of those who scored $8 ; 50 \%$ continued to amplification for scores between 6 and 7 ; and $\sim 78$ continued to amplification to $82 \%$ for scores between 3 and 5 , reinforcing the idea that self-assessment can be an important predictor. $^{20}$

A longitudinal study found that in a period of 5 years, $9.5 \%$ of people who had rated their hearing as good purchased a hearing aid, and $36 \%$ of those who had rated it as bad purchased the aid. Between 5 and 10 years, 41\% of those who reported hearing difficulties purchased hearing aids, and $13 \%$ did not report that, but purchased it anyway. ${ }^{23}$ These data also confirm that one's opinion about their own hearing is a decisive factor for purchase of hearing aids.
-Table 4 show the respondents' scores for the question "On a scale of 1 to 10 , with 1 being the worst and 10 the best, how would you rate your overall hearing ability?" None of the subjects rated their hearing at the worst and best scores of the self-assessment scale ( 1 and 10); furthermore, the median was 5 for both subjects who purchased and those who did not purchase a hearing aid. The mean values for those who purchased and those who did not purchase a hearing aid were 5.3 and 5 points, respectively, thus showing no significant differences $(p=0.68)$. Other authors also found the score 5 as median in the portion of the sample for the reliability test of the question on the self-assessment of hearing, as well as in the research sample. In addition, in the sample that was studied separately to ascertain the reliability of the study, no extreme values ( 1 and 10) were found, either. ${ }^{20}$

Subjects' decision not to purchase hearing aids is likely to be influenced by self-assessment. Other factors, however, cannot be neglected and should be evaluated by speech therapists working in the field.

In a research study with elderly subjects on the use of hearing aids for improving quality of life, aspects such finance, independence, and health were considered for assessment of quality of life by both users and nonusers of hearing aids. Only one of the six respondents in the elderly group of nonusers of hearing aids rated their quality of life as regular because of hearing difficulty. The author of the study pointed out that the elderly rated their quality of life while considering their experiences, and information is required for construction of such experiences. Elderly people usually access information through the radio, television, and the newspaper, which are media that overtly link quality of life to food, physical exercise, and social life. The role of hearing for quality of life is explicit in the literature, but it appears to be inaccessible to most people. ${ }^{28}$ Thus, the impact of hearing loss is not always linked to quality of life because there is no

Table 4 Mean, standard deviation, and median for the score of self-assessment, according to the purchase of hearing aids

\begin{tabular}{|c|c|c|c|c|c|c|c|}
\hline \multirow[t]{3}{*}{ Self-assessment } & \multicolumn{6}{|c|}{ Hearing aid purchase } & \multirow[t]{3}{*}{$p$ Value $^{a}$} \\
\hline & \multicolumn{3}{|c|}{ Yes $(n=22)$} & \multicolumn{3}{|c|}{ No $(n=10)$} & \\
\hline & Mean & Standard deviation & Median & Mean & Standard deviation & Median & \\
\hline Score & 5.3 & 1.6 & 5.0 & 5.0 & 1.8 & 5.0 & 0.688 \\
\hline
\end{tabular}

a Mann-Whitney test (variables with asymmetric distribution). 
information on the implications of the former. Older people may feel that they do not need a hearing aid because they lack information on its benefits and fail to understand the auditory treatment for presbycusis and the related improvements. They may even deny that they have a hearing loss. ${ }^{29}$

Corroborating these data, another study found that only $20 \%$ of individuals seek a hearing center on their own initiative, and the remaining $80 \%$ are equally divided into those who seek help upon medical advice or family counseling. After performing the prosthesis test, $75 \%$ of subjects purchased hearing aids. ${ }^{30}$ Thus, again it appears that middleaged and elderly adults may be unaware of the effects of hearing loss and may not realize the need to use a hearing aid, but after they undergo the necessary tests, they experience the benefit of the hearing aid and are advised to purchase the device.

Other reasons elderly people do not purchase a hearing aid were found by researchers of the Blue Mountains Hearing Study. They found that the third main reason for the elderly not to purchase a hearing aid is that they do not feel they need one (9\%); the first and the second reasons were, respectively, no prescription for use (8\%) and high cost of hearing aids (1.7\%). In addition, they found that 1 out of 10 elderly adults with hearing loss had purchased hearing aids. They pointed out, however, that not all elderly subjects actually used the aids. The predictors for purchase were the presence of hearing loss, self-report of this impairment, and restricted social life. $^{17}$

Many people who would benefit from audiological evaluation and hearing aid are unwilling to do so. For decades, the image of the "deaf old lady" was widespread by the media as one of the marks of old age. Current social and cultural venues for elderly people are places and situations that favor the "young elderly," "dynamic retirees," that is, places and situations where there is a denial of the concept of aging: physical, mental, and social decadence. Among this image of the elderly, being identified as deaf is to be considered as old. Denial of deafness and denial of aging are commonly observed together in this population. ${ }^{31}$

The new concept of aging positively affects the elderly in society. However, those who fail to meet this ideal goal of active elderly feel even more stigmatized. Most elderly people seek to conceal their communication difficulty and protect against stigmatization because they fear to be acknowledged as deaf and old. An alternative to fight the stigma of being old is to hide the hearing loss by means of strategies. However, these attempts result in poor communication and isolation. ${ }^{31}$

Thus, rating their hearing with low scores in self-assessments of hearing means recognizing that hearing loss interferes extensively in life and that something has to be done (i.e., a hearing aid has to be used).

Finally, the survey showed that there was no association between self-assessment of hearing and purchase of hearing aids. It is believed, however, that financial and aesthetic factors, stigma of hearing loss associated with aging, patient's knowledge on the subject, among other factors, have a significant impact on the final decision to purchase a hearing aid.

\section{Conclusions}

The present study showed that although there is evidence that low scores of self-assessment lead to the purchase of hearing aids, this association was not confirmed in this sample.

\section{References}

1 Instituto Brasileiro de Geografia e Estatística - IBGE. Projeções da População-Brasil e Unidades da Federação. Rio de Janeiro, Brazil; 2012. Available at: http://www.ibge.gov.br/home/estatistica/ populacao/projecao_da_populacao/2013/default.shtm. Accessed April 17, 2013

2 Instituto Brasileiro de Geografia e Estatística - IBGE. Diretoria de Pesquisas. Departamento de População e Indicadores Sociais Tábuas de Mortalidade para o Brasil-1991 e 2000. Available at: http://www. ibge.gov.br/home/estatistica/populacao/tabuadevida/evolucao_da_mortalidade.shtm. Accessed December 12, 2014

3 Russo ICP. Distúrbios da audição: presbiacusia. In: Russo ICP, ed. Intervenção fonoaudiológica na terceira idade. 2nd ed. Rio de Janeiro, Brazil: Revinter; 2004:51-82

4 Cózar FA. Presbiacusia. Introducción. Definición In: Gil-Loyzaga P, Carricondo F, eds. Libro Blanco sobre la Presbiacusia. Barcelona, Spain: Gaes; 2013:8-9

5 Kim TS, Chung JW. Evaluation of age-related hearing loss. Korean J Audiol 2013;17(2):50-53

6 Russo ICP. Reabilitação auditiva de idosos. In: Bevilacqua MC, Martinez MAN, Balen SA, Pupo AC, Reis ACMB, Frota S, eds. Tratado de audiologia. 1st ed. São Paulo, Brazil: Santos; 2013:775-787

7 Portmann M, Portmann C. Tratado de Audiometria Clínica. 6th ed. São Paulo, Brazil: Roca; 1993

8 Pinheiro MMC, Iório MCM, Miranda EC, et al. The influence of cognitive aspects and auditory processes on the hearing aid acclimatization in the elderly. J Soc Bras Fonoaudiol 2012;24(4): 309-315

9 Organization for International Standardization-ISO. 7029:2000. Available at: https://www.iso.org/obp/ui/\#iso:std:iso:7029:ed-2: v1:en. Accessed April 10, 2014

10 Yamasoba T, Lin FR, Someya S, Kashio A, Sakamoto T, Kondo K. Current concepts in age-related hearing loss: epidemiology and mechanistic pathways. Hear Res 2013;303:30-38

11 Gates GA, Mills JH. Presbycusis. Lancet 2005;366(9491): $1111-1120$

12 Pronk M, Deeg DJ, Kramer SE. Hearing status in older persons: a significant determinant of depression and loneliness? Results from the longitudinal aging study Amsterdam. Am J Audiol 2013;22(2): 316-320

13 Kouwenberg M, Rieffe C, Theunissen SC, de Rooij M. Peer victimization experienced by children and adolescents who are deaf or hard of hearing. PLoS ONE 2012;7(12):e52174

14 Antunes PC, Silva AM. Elementos sobre a concepção da Meia Idade, no processo de envelhecimento humano. Revista Kairós Gerontologia 2013;16(3):123-140

15 Lin FR, Thorpe R, Gordon-Salant S, Ferrucci L. Hearing loss prevalence and risk factors among older adults in the United States. J Gerontol A Biol Sci Med Sci 2011;66(5):582-590

16 Desai M, Pratt LA, Lentzner H, Robinson KN. Trends in Vision and Hearing among Older Americans. Aging Trends; No. 2. Hyattsville, MD: National Center for Health Statistics; 2001. Available at: http://www.cdc.gov/nchs/data/ahcd/agingtrends/02vision.pdf. Accessed April 10, 2014

17 Gopinath B, Schneider J, Hartley D, et al. Incidence and predictors of hearing aid use and ownership among older adults with hearing loss. Ann Epidemiol 2011;21(7):497-506 
18 Thakur R, Banerjee A, Nikumb V. Health problems among the elderly: a cross-sectional study. Ann Med Health Sci Res 2013; 3(1):19-25

19 Soldera CLC, Teixeira AR, Bós AJG. Fatores associados à utilização de aparelhos de amplificação sonora individual em idosos residentes no estado do rio grande do sul. Revista estudos interdisciplinares sobre o envelhecimento (no prelo)

20 Palmer CV, Solodar HS, Hurley WR, Byrne DC, Williams KO. Selfperception of hearing ability as a strong predictor of hearing aid purchase. J Am Acad Audiol 2009;20(6):341-347

21 Silman S, Silverman CA. Basic audiologic testing. In: Silman S, Silverman CA, eds. Auditory diagnosis: principles and applications. San Diego, CA: Singular Publishing Group; 1997: 44-52

22 World Health Organization. Prevention of blindness and deafness: grades of hearing impairment. Available at: http://apps.who.int/ iris/bitstream/10665/58839/1/WHO_PDH_91.1.pdf?ua=1.

Acessed May 25, 2015

23 Fischer ME, Cruickshanks KJ, Wiley TL, Klein BE, Klein R, Tweed TS. Determinants of hearing aid acquisition in older adults. Am J Public Health 2011;101(8):1449-1455

24 do Carmo LC, Médicis da Silveira JA, Marone SAM, D’Ottaviano FG, Zagati LL, Dias von Söhsten Lins EM. Audiological study of an elderly Brazilian population. Braz J Otorhinolaryngol 2008;74(3): 342-349
25 Pinheiro RS, Viacava F, Travassos C, Brito AS. Gênero, morbidade, acesso e utilização de serviços de saúde no Brasil. Cien Saude Colet 2002;7(4):687-707

26 Guerra TM, Estevanovic LP, Cavalcante MdeÁ, Silva RC, Miranda IC, Quintas VG. Profile of audiometric thresholds and tympanometric curve of elderly patients. Braz J Otorhinolaryngol 2010;76(5): 663-666

27 Teixeira AR, Almeida LG, Jotz GP, et al. Qualidade de vida de adultos e idosos pós adaptação de próteses auditivas. Rev Soc Bras Fonoaudiol 2008;13(4):357-361

28 Teixeira ARO. Uso de prótese auditiva na melhoria da qualidade de vida de idosos: um estudo comparativo entre usuários e não usuários [thesis]. Porto Alegre, Brazil: Pontifícia Universidade Católica do Rio Grande do Sul, Programa de Pós Graduação em Gerontologia Biomédica; 2005:95

29 Lupsakko TA, Kautiainen HJ, Sulkava R. The non-use of hearing aids in people aged 75 years and over in the city of Kuopio in Finland. Eur Arch Otorhinolaryngol 2005;262(3):165-169

30 Cardoso MM, Seimetz BM, Flores LS, et al. Idosos atendidos em um centro auditivo no Sul do Brasil: origem do encaminhamento, restrição de participação social e aquisição de prótese auditiva. Revista Transdisciplinar de Gerontologia 2014;VIII(1):63-69

31 Fialho IM, Almeida ES. Perda auditiva na percepção de idosos. In: Tomé MC, eds. Dialogando com o coletivo. 1st ed. São Paulo, Brazil: Santos; 2009:225-258 